\title{
Mengoptimalkan Pelaksanaan Pendampingan Berbasis KKG Upaya Meningkatkan Kompetensi Guru Kelas Dalam Penyusunan RPP Berdasarkan KTSP Di SD Negeri 42 Ampenan Semester Satu Tahun Pelajaran 2018/2019
}

\author{
Supriadin, Syahrir, Ali Imran \\ Dosen Universitas Pendidikan Mandalika \\ Syahrirmandala85@gmail.com
}

\begin{abstract}
Abstrak; banyaknya guru SD Negeri 42 Ampenan yang tidak membuat Rencana Pelaksanaan Pembelajaran (RPP) ketika mengajar di Kelas, penyebabnya karena rendahnya kompetensi guru SD Negeri 42 Ampenan dalam penyusunan Rencana Pelaksanaan Pembelajaran (RPP) berdasarkan KTSP yang berdampak kurang siapnya guru tampil di Kelas secara prima, solusinya adalah diadakan pembimbingan secara berkelompok. Penelitian ini bertujuan untuk mengetahui seberapa jauh efektifitas pelaksanaan pendampingan dalam upaya meningkatkan kompetensi guru SD Negeri 42 Ampenan dalam penyusunan Rencana Pelaksanaan Pembelajaran (RPP) Berdasarkan KTSP bermanfaat bagi guru dalam peningkatan profesionalisme guru dalam tugas sehari-hari. Dari berbagai kajian teori maka hipotesis tindakan pada penulisan ini adalah : "Pembimbingan kelompok kecil dan perorangan dapat meningkatkan kompetensi guru SD Negeri 42 Ampenan dalam penyusunan RPP berdasarkan KTSP tahun 2016". Penelitian ini dipusatkan di SD Negeri 42 Ampenan sebagai tempat diselenggarakannya pendampingan. Dalam pelaksanaan Penelitian Tindakan Sekolah (PTS) ini sebanyak dua siklus, dimana masing-masing siklus terdapat empat tahapan yaitu perencanaan, pelaksanaan, observasi dan refleksi. Indikator keberhasilan dalam penelitian ini adalah Kompetensi Guru PKn adalah : jika 85 \% dari jumlah peserta pembimbingan telah memperleh nilai rata-rata $\geq 85,00$. Hasil Penelitian Tindakan Sekolah (PTS) pada siklus II diperoleh data sebagai berikut ; 1) observasi Kepala Sekolah $(4,40), 2)$ observasi guru $(4,27), 3)$ Hasil kerja individual $(86,66)$ dan 4) persentase ketuntasan $(100 \%$,). Indikator keberhasilan telah terlampaui Penelitian Tindakan Sekolah (PTS) dinyatakan berhasil, dan penelitian dihentikan pada siklus II. Bimbingan kelompok sangat efektif dalam upaya meningkatkan kompetensi guru dalam penyusunan RPP berbasis pendidikan karakter karena $100 \%$ dari jumlah peserta sebanyak 6 (enam) orang guru telah berhasil menyusun RPP berbasis pendidikan karakter sesuai harapan. Disarankan kpada Kepala Sekolah sejawat untuk melakukan kegiatan pembimbingan bagi guru yang menjadi tanggungjawabnya dalam upaya peningkatan kompetensi guru dalam kegiatan pembelajaran di kelas senyatanya.
\end{abstract}

Kata Kunci : Bimbingan Kelompok - Penyusunan RPP berkarakter

\section{PENDAHULUAN}

Jabatan Kepala Sekolah adalah jabatan yang sangat strategis dalam upaya perwujudan peningkatan mutu pendidikan utamanya di Sekolah yang menjadi tanggung jawabnya. Keberhasilan mutu pendidikan yang tercermin pada perolehan hasil kinerja bagi guru binaannya merupakan bentuk nyata kepedulian kepala sekolah dalam menjalankan delapan (8) standar pendidikan di sekolahnya. Keberhasilan/kegagalan sekolah merupakan tanggung jawab moral secara langsung maupun secara tidak langsung bagi kepala sekolah, sehingga Abdi Masyarakat diperlukan upaya nyata yang tercermin dalam kegiatan sesuai dengan tugas pokok dang fungsi (Tupoksi) dari lima tupoksi kompetensi kepala sekolah yaitu; 1) kepribadian, 2) manajerial, 3) pedagodik, 4) kewirausahaan, dan 5) sosial. Dari kelima kompetensi itu seorang kepala sekolah harus mampu menselaraskan dalam pelaksanaannya. Skala prioritas perlu dilaksanakan bila mana salah satu kompetensi sangat perlu didahulukan.

Berdasarkan hasil supervisi Kepala SD Negeri 42 Ampenan terhadap 6 (enam) orang guru yang yang masih berstatus sebagai 
guru honorer, dijumpai permasalahanpermasalahan nyata yang perlu segera di tindak lanjuti. Permasalahan itu antara lain; 1) guru mengajar di kelas hanya membawa buku paket dan daftar nilai saja, 2) guru mengajar tidak membuat Rencana Pelaksanaan Pembelajaran (RPP), 3) ada yang membawa RPP tetapi sifatnya hanya copy paste, 4) bahkan yang lebih parah lagi RPP yang dibawa di Kelas hanya sebagai hiasan saja, sementara mengajar hanya mengacu pada urutan buku paket terbitan swasta, sedangkan yang ke 5) guru belum ada yang memasukkan nilai-nilai karakter bangsa walaupun dalam pelaksanaannya secara tidak langsung sudah menerapkan pendidikan karakter bangsa.

Permasalahan diatas, hal yang dianggap penting dan sangat penting untuk dicari solusinya adalah : rendahnya kompetensi guru SD Negeri 42 Ampenan dalam penyusunan Rencana Pelaksanaan Pembelajaran (RPP) berdasarkan KTSP yang berdampak kurang siapnya guru tampil di Kelas secara prima. Guru asal mengajar tanpa konsep metode yang jelas, selama proses pembelajaran gurulah yang aktif menampilkan kebolehannya di depan siswanya, sementara siswa hanya duduk manis mendengarkan penjelasan guru sampai akhir pelajaran. Tujuan pembelajaran tidak jelas, tidak memperhitungkan waktu sehingga sampai bel berbunyi masih saja asyik menjelaskan/bercerita menurut kemauan guru semata.

Dengan mengoptimalkan pelaksanaan pendampingan dalam penyusunan RPP berdasarkan KTSP ini diharapkan mampu meningkatkan kompetensi guru yang professional dalam proses pembelajaran yang diawali dengan hadirnya RPP yang berdasarkan KTSP sehingga upaya untuk membangkitkan minat belajar bias terwujud yang ditandai dengan semangat belajar yang tinggi dan motivasi belajar yang mampu meningkatkan hasil belajar siswa di kelas senyatanya.

Untuk mengaktualisasikan perencanaan ini, perlu diadakan Penelitian Tindakan Sekolah (PTS) dengan judul "Mengoptimalkan Pelaksanaan
Pendampingan Berbasis KKG Upaya Meningkatkan Kompetensi Guru Kelas Dalam Penyusunan RPP Berdasarkan KTSP Di SD Negeri 42 Ampenan Semester Satu Tahun Pelajaran 2018/2019.

\section{Manfaat Pengabdian}

Secara praktis hasil Penelitian Tindakan Sekolah (PTS) ini sangat berguna bagi; 1) Kepala SD Negeri 42 Ampenan selaku peneliti dalam rangka melaksanakan pendampingan, 2) guru dalam meningkatkan mutu proses pembelajaran di kelas senyatanya yang diawali dengan penyusunan RPP berdasarkan KTSP.

\section{KAJIAN PUSTAKA}

\section{Kompetensi}

Ahli pendidikan lain berpendapat, kompetensi merupakan perilaku yang rasional untuk mencapai tujuan yang diisyaratkan sesuai kondisi yang diharapkan. Adapun kompetensi guru (teacher competency) merupakan kemampuan seorang guru dalam melaksanakan kewajiban-kewajiban secara bertanggung jawab dan layak (Uzer Usman, 2001;14). Dalam penelitian ini, dimaksud dengan kompetensi guru adalah kemampuan dalam menyususn RPP berbasis pendidikan karakter.

\section{Rencana Pelaksanaan Pembelajaran (RPP)}

"Rencana Pelaksanaan Pembelajaran (RPP) adalah rancangan pembelajaran mata pelajaran perunit yang akan diterapkan guru dalam pembelajaran di kelas. Berdasarkan RPP inilah seorang guru (baik yang menyusun RPP itu sendiri maupun yang bukan) diharapkan bisa menerapkan pembelajaran secara terprogram. Oleh karena itu, RPP harus mempunyai daya terap (aplicable) yag tinggi. Pada sisi lain, melalui RPP pun dapat diketahui kadar kemampuan guru dalam menjalankan profesinya (Mansyur Muslich, dalam Aswandi, 2010)"

Adapun langkah-langkah yang harus diterapkan oleh guru dalam penyusunan Rencana Pelaksanaan Pembelajaran (RPP) adalah sebagai berikut :

1. Ambillah satu unit pembelajaran yang akan diterapkan dalam pembelajaran

2. Tulis standar kompetensi dan kompetensi dasar yang terdapat dalam unit tersebut. 
3. Tentukan indikator untuk mencapai kompetensi dasar tersebut.

4. Tentukan alokasi waktu yang diperlukan untuk mencapai indikator tersebut

5. Rumuskan tujuan pembelajaran yang ingin dicapai dalam pembelajaran tersebut

6. Tentukan materi pembelajaran yang akan diberikan/dikenakan kepada siswa untuk mencapai tujuan pembelajaran yang telah dirumuskan.

7. Pilihlah metode pembelajaran yang dapat mendukung sifat materi dan tujuan pembelajaran

8. Susunlah langkah-langkah kegiatan pembelajaran pada setiap satuan rumusan tujuan pembelajaran, yang bisa dikelompokkan menjadi kegiatan awal, kegiatan inti, dan kegiatan penutup.

9. Jika alokasi waktu untuk mencapai satu kompetensi dasar lebih dari 2 (dua) jam pelajaran, bagilah langkah-langkah pembelajaran menjadi lebih dari satu pertemuan. Pembagian setiap jam pertemuan bisa didasarkan pada satuan tujuan pembelajaran atau sifat/tipe/jenis materi pembelajaran.

10. Sebutkan sumber/media belajar yang akan digunakan dalam pembelajaran secara konkret dan utuk setiap bagian/unit pertemuan.

11. Tentukan teknik penilaian, bentuk dan contoh instrumen penilaian yang akan digunakan untuk mengukur ketercapaian kompetensi dasar atau tujuan pembelajaran yang telah dirumuskan. Jika instrumen penilian berbentuk tugas, rumuskan tugas tersebut secara jelas dan bagaimana rambu-rambu penilaiannya. Jika instrumen penilaian berbentuk soal, cantumkan soal-soal tersebut dan tentukan rambu-ramu penilaiannya dan/atau kunci jawabannya. Jika penilainnya berbentuk proses, susunlah rubriknya dan indikator masingmasingnya.

(Mansyur Muslich, dalam Aswandi, 2010)

\section{Pendampingan}

Menurut Hartinah, dalam bukunya “Konsep Dasar Pendampingan”, berpendapat bahwa :

"Hakekat pendekatan kelompok ditinjau dari metode pendekatannya, secara garis besar bimbingan dapat dibedakan dalam dua cara, yaitu : 1) Teknik pendekatan secara individual dan 2) Teknik pendekatan secara kelompok. Teknik pendekatan individual, yaitu bimbingan yang diartikan secara individual atau perorangan. Hal tersebut sering dikenal dengan istilah "Individual Conseling" karena pembimbingan tersebut dilakukan secara individual. Berbeda dengan teknik pendekatan secara kelompok, yaitu bimbingan yang dilaksanakan secara kelompok terhadap sejumlah individu sekaligus sehingga beberapa orang atau individu sekaligus dapat menerima bimbingan yang dimaksudkan".

\section{(2009: 4)}

Strategi yang digunakan dalam pembimbingan ini adalah pendampingan kecil. Teknik ini dapat dijelaskan sebagai berikut :

Kegunaan pendampingan adalah :

1. Pembimbing dapat melayani secara berkelompok maupun secara perorangan karena jumlah peserta pembimbingan 37 orang guru.

2. melalui pendampingan kecil guru dilatih menghadapi suatu tugas yang harus di pecahkan.

3. Mendorong kepada peserta untuk berani bertanya dan mengemukakan pendapatnya.

4. Banyak informasi yang bisa dibutuhkan dalam tugas kelompok kecil atau perorangan.

5. Melalui pendampingan guru semakin sadar akan kelebihan dan kekurangannya

6. Melatih percaya diri dan berani mencoba apa yang dikuasainya.

adalah guru SD Negeri 42 Ampenan berjumlah 6 (enam) orang guru yang mengalami kesulitan dalam penyusunan RPP berbasis pendidikan karakter. Integrasi pendidikan karakter dalam pembelajaran di kelas senyatanya merupakan sasaran utama 
dalam upaya peningkatan kompetensi guru dalam Penelitin Tindakan Sekolah (PTS) ini.

\section{Kelompok Kerja Guru (KKG)}

Trimo (2007: 12) Kelompok Kerja Guru yaitu suatu organisasi profesi guru yang bersifat struktural yang dibentuk oleh guruguru di suatu wilayah atau gugus sekolah sebagai wahana untuk saling bertukaran pengalaman guna meningkatkan kemampuan guru dan memperbaiki kualitas pembelajaran.

Menurut Buchari Zainun 1987 (dalam, Suryosubroto 2004: 1) ada lima faktor yang mendasari kegiatan manusia dalam organisasi yaitu:

a. Faktor spesialisasi dan pembagian kerja;

b. Faktor koordinasi;

c. Faktor tujuan;

d. Faktor prosedur kerja;

e. Faktor dinamika lingkungan.

Sedangkan Sumadji (2013: 1) menyatakan, "Kelompok kerja guru ini merupakan wadah atau tempat bagi guru untuk bermusyawarah tentang hal-hal untuk peningkatan mutu dalam pembelajaran". Pedoman Pembinaan Gugus PAUD (2012: 3) menyatakan bahwa "Kelompok Kerja Guru (KKG) PAUD merupakan program kerja gugus sebagai wahana bengkel kerja guruguru anggota Gugus". Pendapat lain dikatakan oleh Uceh Nurabnu (2012: 24), Kelompok Kerja Guru (KKG) TK/PAUD "merupakan salah satu bagian dari program kerja gugus sebagai wahana bengkel kerja guru-guru TK/PAUD selaku anggota gugus, dan merupakan pintu masuk pertama yang paling strategis dalam program peningkatan kompetensi pendidik TK/PAUD”.

Melalui KKG guru memiliki kesempatan dan berpotensi mendiskusikan penyelesaian permasalahan yang dihadapi di kelas. Trimo (2007: 12) menyatakan, "pembinaan melalui KKG memberikan kesempatan bagi guru yang lebih luas (dimungkinkan semua guru terlibat), dibanding bentuk pembinaan yang lain (harus menunggu kesempatan)". Uceh Nurabnu (2012: 24) Gugus TK merupakan wadah kegiatan Kelompok Kerja Guru (KKG) dan Kelompok Kerja Kepala TK (KKKTK) yang telah ditetapkan melalui Direktur Jendral
Pendidikan Dasar dan Menengah, Departemen Pendidikan dan Kebudayaan Nomor 086/c/Kep/v/tanggal 8 Mei 1995. Standar pengembangan KKG Derektorat Profesi Pendidik Direktorat Jendral Peningkatan Mutu Pendidikan dan Tenaga Kependidikan Departemen Pendidikan dan Kebudayaan Republik Indonesia menyatakan bahwa KKG merupakan wadah atau forum kegiatan profesional bagi para guru Sekolah Dasar/Madrasah Ibtidaiyah di tingkat gugus atau kecamatan yang terdiri dari beberapa guru dari berbagai sekolah".

Menurut Standar Pengembangan KKG Derektorat Profesi Pendidik Direktorat Jendral Peningkatan Mutu Pendidikan dan Tenaga Kependidikan Departemen Pendidikan dan Kebudayaan Republik Indonesia, tujuan KKG adalah:

a. Memperluas wawasan dan pengetahuan guru dalam berbagai hal, khususnya penguasaan substansi materi pembelajaran, penyusunan silabus, penyusunan bahanbahan pembelajaran, strategi pembelajaran, metode pembelajaran, memaksimalkan pemakaian sarana/prasarana belajar, memanfaatkan sumber belajar, dsb

b. Memberikan kesempatan kepada anggota kelompok kerja atau musyawarah kerja untuk berbagi pengalaman serta saling memberikan bantuan dan umpan balik;

c. Meningkatkan pengetahuan dan keterampilan, serta mengadopsi pendekatan pembaharuan dalam pembelajaran yang lebih profesional bagi peserta kelompok kerja atau musyawarah kerja;

d. Memberdayaan dan membantu anggota kelompok kerja dalam melaksanakan tugas-tugas pembelajaran di sekolah;

e. Mengubah budaya kerja anggota kelompok kerja atau musyawarah kerja (meningkatkan pengetahuan, kompetensi dan kinerja) dan mengembangkan profesionalisme guru melalui kegiatankegiatan pengembangan profesionalisme di tingkat $\mathrm{KKG} / \mathrm{KKG}$; 
f. Meningkatkan mutu proses pendidikan dan pembelajaran yang tercermin dari peningkatan hasil belajar peserta didik;

g. Meningkatkan kompetensi guru melalui kegiatan-kegiatan di tingkat $\mathrm{KKG} / \mathrm{KKG}$.

Yang dimaksud dengan kelompok kerja guru (KKG) dalam penelitian ini adalah 6 (enam) guru SD Negeri32 Mataram yang menjadi sasaran dalam pelaksanaan pendampingan dalam penyusunan RPP berdasarkan Kurikulum 2006 (KTSP). Kegiatan nyata KKG SDNegeri 32 Mataram yaitu penysunan Rencana Pelaksanaan Pembelajaran )RPP) yang dibimbing langsung oleh kepala sekolah selaku peneliti. Dalam kegiatan ini semua guru kelas dari kelas I sampai dengan guru kelas VI menyusun RPP secara individualdalam forum KKG. Kendala/kesulitan yang dialami oleh guru langsung diberikan bimbingan, perbaikan, dan penyempurnaansesuai dengan situasi dan kondisi pada saat KKG yang diselenggarakan di SD Negeri 46 Cakranegara.

\section{Kerangka Konseptual}

Untuk mendapatkan gambaran riil dalam pelaksanaan Penelitian Tindakan Sekolah (PTS) ini, dapat digambarkan sebagai berikut:

1. Kepala Sekolah selaku peneliti melakukan pembimbingan terhadap 6 (enam) orang guru SD Negeri 42 Ampenan.

2. Pelaksanaan bimbingan dalam bentuk kelompok kecil.

3. Selama kerja kelompok dalam menyusun RPP, sesama anggota kelompok berdiskusi untuk mendapatkan hasil yang diharapkan.

4. Setelah selesai pendampingan, secara individu setiap guru diberi tugas membuat RPP sesuai kelas yang diajarnya.

5. Selama guru mengerjakan tugas, bila memerlukan bimbingan bisa sewaktuwaktu menemui Kepala Sekolah dan akan bertanya kepada teman sejawat.

6. Hasil RPP dinilai dan dijadikan sebagai dasar untuk perbaikan pada kegiatan berikutnya.

\section{Hipotesis Tindakan}

"Pendampingan kecil dan perorangan

dapat meningkatkan kompetensi guru SD
Negeri 42 Ampenan dalam penyusunan RPP berdasarkan KTSP tahun 2016"

METODE PELAKSANAAN

Lokasi

Penelitian Tindakan Sekolah (PTS) ini dilaksanakan di SD Negeri 42 Ampenan, dengan melibatkan 6 (enam) guru kelas.

\section{Variabel}

\section{Input :}

1. Bagaimana kesiapan Kepala Sekolah selaku peneliti dalam merencanakan pempendampingan kecil dan perorangan

2. Bagaimana kesiapan guru untuk menyusun Rencana Pelaksanaan Pembelajaran (RPP) berdasarkan KTSP

\section{Variabel Proses :}

1. Bagaimana proses pelaksanaan pempendampingan kecil

2. Bagaimana kemampuan guru dalam penyusunan RPP berdasarkan KTSP

\section{Variabel Output :}

1. Bagaimana hasil pempendampingan kecil

2. Seberapa jauh kemampuan guru dalam menyusun RPP berdasarkan KTSP

\section{Teknik Pengumpulan Data}

\section{Sumber Data}

Yang menjadi sumber data dalam penelitian Tindakan Sekolah (PTS) ini adalah guru SD Negeri 42 Ampenan yang terdiri dari 6 (enam) orang guru yang memerlukan bimbingan dalam penyusunan RPP berdasarkan KTSP

\section{Jenis Data}

Data yang berasal dari Kepala Sekolah/peneliti meliputi :

- Rencana Pelaksanaan Pembimbingan (RPP)

- Lembar observasi Kepala Sekolah /peneliti

- Lembar observasi guru Data yang berasal dari guru

- Lembar hasil diskusi kelompok berupa draf RPP

- Rencana Pelaksanaan Pembelajaran (RPP) berdasarkan KTSP

\section{Teknik Pembahasan}

Adapun teknik pembahasan hasil penelitian tindakan sekolah (PTS) ini adalah melalui tahapan pada setiap siklus sebagai berikut : 


\section{Tahap Perencanaan}

Pada tahapan ini yang perlu dibahas adalah: a) bagaimana hasil penyusunan Rencana Pelaksanaan Pembimbingan (RPP) yang dibuat oleh peneliti, apakah sudah sesuai atau masih perlu perbaikan, b) Penyiapan alat bahan ajar, apakah ada kendala yang harus di cari solusi pemecahannya atau ada yang harus di perbaiki dan di sesuaikan dengan rencana yang telah di tuangkan pada RPP, c) Penyusunan lembar observasi Kepala Sekolah dan lembar observasi guru apakah ada yang harus di revisi atau sudah sesuai dengan jenis kegiatan yang dilaksanakan, d) Penyusunan alat evaluasi terkait dengan materi pembimbingan yaitu sekitar penyusunan RPP berdasarkan KTSP.

\section{Tahap Pelaksanaan}

Pembahasan pada tahap pelaksanaan pembimbingan terhadap tiga puluh tujuh guru SD Negeri 42 Ampenan melalui pendampingan kecil ini adalah: a) Apakah ada kendala yang dihadapi selama pembimbingan, b) apa yang menyebabkan kendala itu terjadi, c) dan bagaimana solusi pemecahannya, serta apa hasilnya setelah diberikan solusi pemecahannya.

\section{Tahap Observasi}

Pada tahapan ini peneliti membahas permasalahan teknis terkait dengan pelaksanaan observasi yang meliputi: a) observasi pelaksanaan bimbingan oleh peneliti, b) observasi selama kegiatan diskusi kelompok kecil yang membahas masalah penyusunan RPP berdasarkan KTSP.

\section{Tahap Refleksi}

Pada tahapan ini peneliti membahas tentang: a) hasil observasi oleh observers pada saat melakukan pengamatan selama pelaksanaan pempendampingan kecil, b) tindakan apa yang harus dilakukan untuk memecahkan permasalahan-permasalahan yang dihadapi oleh peneliti dan permasalahan yang dihadapi oleh guru dalam penyusunan RPP berdasarkan KTSP, c) jenis penguatan apa agar guru termotivasi untuk memperbaiki kesalahan, dan d) menjabarkan jenis tindakan apa dalam upaya kegiatan tindak lanjut

\section{Rancangan Penelitian} Skenario Tindakan

Abdi Masyarakat
Untuk mendapatkan gambaran tahapan kegiatan masing-masing siklus dapat dilihat pada gambar sebagai berikut:

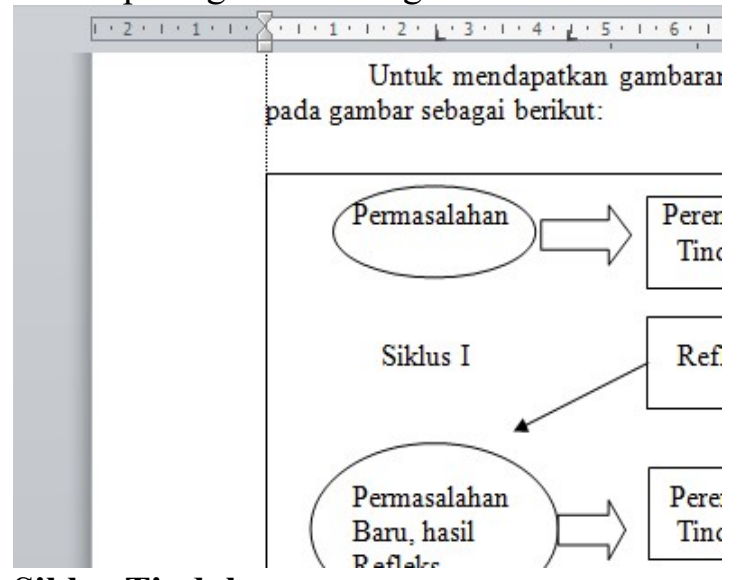

Siklus Tindakan

\section{SIKLUS I}

\section{Tahap I : Perencanaan Tindakan}

1.1. Menyusun Rencana Pelaksanaan Pembimbingan (RPP)

1.2. Menyiapkan alat dan sumber bahan yang diperlukan dalam penelitian

1.3. Menyusun instrumen observasi Kepala Sekolah/peneliti dan instrumen observasi guru

1.4. Menyusun pedoman analisis hasil observasi

1.5. Membuatkan jadwal kegiatan pembimbingan

Tahap II : Pelaksanaan Tindakan

Pertemuan I (Melaksanakan pendampingan kecil)

1.1. Menyampaikan materi pembimbingan

1.2. Melaksanakan diskusi kelompok kecil

1.3. Memberikan pendampingan kecil

1.4. Memberikan solusi terhadap permasalahan yang ada

1.5. Memberikan penguatan/reward

Pertemuan II

a. Dikerjakan di luar jam tatap muka.

b. Bisa di rumah dan atau di sekolah pada saat tidak ada jam mengajar

c. Bila mengalami kendala/kesulitan bisa bertanya langsung kepada peneliti dan atau kepada teman sejawat.

Tahap III. Pengamatan/pengumpulan data

- Mengawasi kegiatan Kepala Sekolah/peneliti oleh pengawas pembimbing 
- Mengamati kegiatan diskusi kelompok kecil

- Mengamati dan menganalisis hasil observasi

- Menilai hasil kerja individual dalam penyusunan RPP berdasarkan KTSP

Tahap IV. Refleksi

- Renungan/pemikiran atas data hasil observasi

- Perbaikan dan penyempurnaan jenis tindakan

- Memberi saran perbaikan dan solusinya

- Memberikan penguatan/reward atas hasil observasi

- Menyusun rencana tindakan lanjut/rekomendasi atas hasil capaian pada siklus yang telah dilakukan

\section{SIKLUS II}

Pada dasarnya semua jenis tindakan yang dilakukan pada siklus II ini sama dengan siklus I, hanya saja terdapat penyempurnaan/perbaikan sesuai dengan harapan. Untuk mendapatkan gambaran nyata tentang kegiatan siklus II dapat diuraikan sebagai berikut:

\section{Indikator Keberhasilan/Kinerja}

1. Proses pempendampingan dinyatakan telah berhasil jika skor rata-rata hasil observasi yang diperoleh oleh pembimbing maupun terbimbing (guru) $\geq$ 4,0 (empat koma nol/kategori baik)

2. Kompetensi guru SD Negeri 42 Ampenan dalam penyusunan RPP berbasis pendidikan karakter dinyatakan telah meningkat jika $85 \%$ dari jumlah peserta pembimbingan telah memperoleh nilai rata-rata $\geq 85$.

\section{LAPORAN HASIL}

\section{Deskripsi Siklus I}

Perencanaan Tindakan.

Pada tahapan ini Kepala Sekolah selaku peneliti telah melakukan kegiatankegiatan nyata sebagai berikut: menyusun Rencana Pelaksanaan Pembimbingan (RPP), menyiapkan semua alat yang diperlukan selama pembimbingan, membuatInstrumen observasi yang dibuat ada dua macam yaitu instrumen observasi kepala sekolah, dan instrumen observasi guru peserta pembimbingan, membuat pedoman analisis hasil observasi Kepala Sekolah dan hasil observasi guru sekaligus analisis hasil nilai guru dalam penyusunan Rencana Pelaksanaan Pembelajaran (RPP) berdasarkan KTSP.

\section{Peaksanaan Tindakan}

Peneliti menyampaikan materi pembimbingan dalam penyusunan Rencana Pelaksanaan Pembimbingan (RPP) berdasarkan KTSP. Pada kegiatan ini diawali dengan penjelasan singkat tentang tata cara menyusun RPP yang dipadukan dengan pendidikan karakter bangsa yang melibatkan aktifitas dari guru peserta pembimbingan dalam bentuk tanya jawab sekitar tata cara memadukan antara RPP dengan pendidikan karakter bangsa.

Selama guru melaksanakan diskusi kelompok/kerja kelompok, penelit berkeliling dari kelompok satu ke keompok yang lain untuk memberikan bimbingan secara berkelompok maupun secara individual dalam penulisan Rencana Pelaksanaan Pembelajaran (RPP) berdasarkan KTSP. Bagi kelompok yang dianggap berjalan lancar, peneliti hanya memberikan penguatan. Tetapi bagi kelompok yang mengalami kesulitan maka peneliti lebih lama dan lebih jeli dalam melakukan pembimbingan.

Pada pertemuan berikutnya, guru diberi tugas mandiri untuk menyusun RPP berdasarkan KTSP dengan ketentuan :

1. Dikerjakan diluar tatap muka/pekerjaan rumah (PR)

2. Dikerjakan di sekolah pada saat guru tidak ada jam mengajar.

3. Bila kesulitan agar berkomunikasi dengan teman sejawat dan atau berkomunikasi langsung dengan Kepala Sekolah.

\section{Pengamatan/Observaasi dan pengumpulan} data

Hasil observasi Kelapa Sekolah oleh observers memperoleh skor rata-rata sebesar 3,50, hasil observasi guru memperoleh skor rata-rata sebesar 3,53, dan Perolehan nilai hasil kerja individual memperoleh nilai ratarata sebesar 78,04. 


\section{Refleksi}

Peneliti merenung atas data hasil observasi yang dipandang masih belum mencerminkan dari indikator keberhasilan yang telah ditetapkan yaitu hasil observasi Kepala Sekolah maupun hasil observasi guru peserta pembimbingan dalam penyusun RPP berdasarkan KTSP adalah $\geq 4,0$, sedangkan perolehan nilai hasil penyusunan RPP $85 \%$ dari jumlah guru memperoleh nilai rata-rata $\geq$ 85,00 .

Karena indikator keberhasilan belum tercapai maka peneliti; 1) melanjutkan pembimbingan, 2) penelitian tindakan sekolah (PTS) dilanjutkan pada siklus II, 3) peneliti berupaya mengoptimalkan pelaksanaan pembimbingan dengan strategi yang mampu membangkitkan semangat guru dalam melaksanakan diskusi kelompok/kerja kelompok maupun dalam mengerjakan tugas individual diluar jam pembimbingan sehingga RPP yang dibuat mampu menghasilkan sesuai harapan, 4) mengupayakan agar indikator keberhasilan dapat dicapai dan atau dapat dilampaui.

\section{Deskripsi Siklus II \\ Perencanaan Tindakan}

Pada tahapan ini Kepala Sekolah selaku peneliti telah melakukan kegiatankegiatan nyata yang tidak jauh berbeda dengan tahap awal pada siklus I tetapi dilengkapi dengan penyempurnaan kekurangan-kekurangan yang ada pada siklus I.

\section{Pelaksanaan Tindakan}

Peneliti merefleksi perolehan hasil observasi Kepala sekolah, observasi guru, dan perolehan nilai hasil kerja individual untuk dicari solusi terkait dalam pelaksanaan bimbingan pada siklus II. Selanjutnya peneliti menjelaskan secara rinci materi pembimbingan dikaitkan dengan perolehan hasil pada siklus I. Penyampaian materi ini menggunakan strategi yang sama tetapi lebih di tekankan agar peserta lebih cepat menyerap dan dapat melakukan dengan sebaik-baiknya dan hasil yang diperolehnya mampu menjawab indikator keberhasilan yang telah ditetapkan.
Pada pertemuan ini dalam bentuk tugas mandiri secara individual yang dikerjakan dirumah dan atau di sekolah pada saat tidak ada jam mengajar. Apabila ada kesulitan bisa berdiskusi dengan teman sejawat dan atau bertanya langsung kepada Kepala Sekolah selaku peneliti.

Pengamatan/observasi dan pengumpulan data.

Hasil observasi Kelapa Sekolah oleh observers memperoleh skor rata-rata sebesar 4,40, hasil observasi guru memperoleh skor rata-rata sebesar 4,27, dan Perolehan nilai hasil kerja individual memperoleh nilai ratarata sebesar 86,66

\section{Refleksi}

Mencermati data hasil tindakan pada siklus II, upaya Kepala Sekolah selaku peneliti untuk mengoptimalkan pelaksanaan pempendampingan maupun bimbingan secara individual dengan pendekatan, strategi, dan metode yang jitu telah mampu melampaui indikator keberhasilan yang telah ditetapkan. Peneliti sudah berhasil melakukan pembimbingan yang akan terus ditingkatkan dan dipertahankan dalam kegiatan yang sama pada waktu berikutnya.

Peneliti memberikan penghargaan, penguatan kepada semua guru peserta pembimbingan disertai dengan harapan agar dimasa mendatang setiap menyusun RPP agar mempedomani hasil yang telah dicapai selama proses pembimbingan dan hasil kerja secara individual dalam penyusunan RPP berdasarkan KTSP khususnya bagi semua guru SD Negeri 42 Ampenan.

\section{PEMBAHASAN}

\section{SIKLUS I}

\section{Perencanaan Tindakan}

Peneliti telah berhasil menyusun Rencana Pelaksanaan Pembimbingan (RPP) berdasarkan KTSP, menyiapkan semua alat, sumber, bahan diperlukan selaa proses tindakan, menyusun instrument observasi Kepala Sekolah dan instrument guru serta penyusunan pedoman analisis hasil observasi Kepala Sekolah dan observasi guru serta analisis hasil nilai guru. Kegiatan diatas yang mengalami hambatan yaitu dalam penyusunan instrument observasi Kepala Sekolah dan 
instrument observasi guru. Peneliti masih belum memahami benar tentang instrument mana yang harus ditampilkan selama observasi sehingga pelaksanaan tindakan dapat terukur dan sesuai dengan harapan indikator keberhasilan yang telah ditetapkan

\section{Pelaksanaan Tindakan}

Pada kegiatan ini peneliti telah
melakukan tindakan sesuai dengan perencanaan yaitu ; 1) menyampaikan materi pembimbingan dalam penyusunan RPP berdasarkan KTSP, 2) menguji pelaksanaan diskusi kelompok yang kegiatannya adalah menyusun RPP secara berkelompok sesuai dengan bidang studi/mata pelajaran yang diampunya, 3) peneliti berkeliling membimbing kelompok terutama kelompok yang mengalami kesulitan dan memerlukan bimbingan secara khusus, 4) setiap kelompok yang mengalami kesulitan diberikan solusi agar kelompok mampu memecahkan masalah yang terjadi dan yang ke 5) peneliti telah mendapatkan hasil optimal dari hasil kerja kelompok yang selanjutnya dijadikan bahan pertimbangan dalam melaksanakan bimbingan pada tahap berikutnya.

\section{Observasi/Pengumpulan Data}

Hasilnya observer menerima dan melakukan pengamatan sesuai dengan instrumen yang telah disiapkan. Perolehan skor rata-rata pada sklus I ini adalah $(3,50)$ ini artinya indikator keberhasilan belum tercapai. Hasilnya proses pembimbingan berjalan lancar dan hasil skor rata-rata yang diperoleh oleh 6 (enam) orang guru selama mengikuti pembimbingan adalah $(3,53)$ ini artinya belum memenuhi indikator keberhasilan yang telah diisyaratkan.

\section{Refleksi}

Hasil observasi Kepala Sekolah, hasil observasi guru, dan perolehan nilai rata-rata penyusunan proposal Penelitian Tindakan Sekolah (PTS) secara berturut-turut memperoleh hasil sebagai berikut : $(3,50)$, $(3,53)$, dan $(78,04)$. Hasil ini masih belum memenuhi indikator keberhasilan dimana untuk observasi Kepala Sekolah maupun observasi guru diharapkan memperoleh skor rata-rata $\geq 4,0$ dan penyusunan $R P P$ diharapkan memperoleh nilai rata-rata $\geq$ 85,00 .

\section{Siklus II}

\section{Perencanaaan Tindakan}

Pada tahapan perencanaan tindakan ini yang kegiatannya meliputi ; 1) penyusunan Rencana Pembimbingan ( RPP ), 2) penyediaan alat, sumber bahan, 3) penyusunan lembar observasi, 4) menyusun pedoman analisa hasil observasi, dan 5) pembuatan jadwal kegiatan pembimbingan, pada prinsipnya sama dengan apa yang dilakukan pada siklus I. Penekanan pada kegiatan ini adalah perbaikan dan penyempurnaan kekurangan dan kesalahan yang pernah dilakukan pada siklus I. Secara umum hambatan tidak ada, begitupun faktor penyebabnya juga tidak ada, sehingga adalam penyusunan perencanaan tindakan pada siklus II berjalan sesuai dengan apa yang telah direncanakan.

\section{Pelaksanaan Tindakan}

Pada kegiatan ini peneliti telah melakukan tindakan sesuai dengan perencanaan yaitu ; 1) menyampaikan materi pembimbingan dalam penyusunan RPP berdasarkan KTSP, 2) menguji pelaksanaan diskusi kelompok yang kegiatannya adalah menyusun RPP secara berkelompok sesuai dengan bidang studi/mata pelajaran yang diampunya, 3) peneliti berkeliling membimbing kelompok terutama kelompok yang mengalami kesulitan dan memerlukan bimbingan secara khusus, 4) setiap kelompok yang mengalami kesulitan diberikan solusi agar kelompok mampu memecahkan masalah yang terjadi dan yang ke 5) peneliti telah mendapatkan hasil optimal dari hasil kerja kelompok yang selanjutnya dijadikan bahan pertimbangan dalam melaksanakan bimbingan pada tahap berikutnya.

Yang dilakukan oleh peneliti pada tahapan ini adalah : 1) member tugas secara individual dalam menyusun RPP berdasarkan KTSP sesuai dengan bidang studi/mata pelajaran yang diampunya, 2) tugas dilakukan diluar jam tatap muka, bias dikerjakan dirumah dan disekolah pada saat tidak ada jam mengajar, 3) bila mengalami kesulitan agar berkolaborasi dengan teman sejawat dan 
atau bias berkonsultasi langsung dengan Kepala Sekolah selaku peneliti.

\section{Observasi/Pengamatan dan Pengumpulan} Data

Kegiatan pengamatan terhadap proses pembimbingan yang dilakukan Kepala Sekolah selaku peneliti oleh pengawas sejawat selaku observer berjalan lancar artinya tidak mengalami hambatan. Pada kegiatan ini Kepala Sekolah memperoleh skor rata-rata $(4,40)$, sementara perolehan skor rata-rata hasil pengamatan kegiatan guru dalam kelompok adalah $(4,27)$ ini artinya kedua kegiatan itu sudah melampui indikator keberhasilan yang telah ditetapkan yaitu $\geq$ 4,0. Sementara hasil nilai rata-rata dari penyusunan RPP berdasarkan KTSP adalah $(86,66)$, ini artinya ini artinya indikator keberhasilan $(85,00)$ telah terlampaui. Sedangkan keberhasilan secara individual yang mengikuti pembimbingan dalam penyusunan RPP berdasarkan KTSP sudah berhasil dengan memperoleh presentase 100 $\%$. Sedangkan keberhasilan secara klasikal memperoleh nilai rata-rata $(86,66)$.

\section{Refleksi}

Setelah selesai siklus II Kepala Sekolah selaku peneliti diberikan beberapa saran dari observer antara lain : 1) proses pembimbingan sudah baik tetapi masih perlu ditingkatkan, 2) sebagian besar guru peserta pembimbingan sudah merasa senang dan bisa menerima materi serta dapat mempraktekkan secara langsung, tetapi masih ada peserta yang masih kelihatan kurang mengerti. Selanjutnya peneliti menganalisis data perolehan pada siklus II. Hasil observasi Kepala Sekolah memperoleh skor rata-rata $(4,40)$, hasil observasi guru memperoleh skor rata-rata $(4,27)$, dan nilai rata-rata hasil penyusunan RPP berdasarkan KTSP $(86,66)$.

Karena indikator keberhasilan sudah tercapai maka Penelitian Tindakan Sekolah (PTS) dengan judul : "Mengoptimalkan Pelaksanaan Pendampingan Berbasis KKG Upaya Meningkatkan Kompetensi Guru Kelas Dalam Penyusunan RPP Berdasarkan KTSP Di SD Negeri 42 Ampenan Semester Satu Tahun Pelajaran 2018/2019" dinyatakan telah
"BERHASIL", maka Penelitian Tindakan Sekolah (PTS) dihentikan pada "SIKLUS II". SIMPULAN

Pendampingan berbasis $\mathrm{KKG}$ sangat efektif dalam upaya meningkatkan kompetensi guru dalam penyusunan RPP berdasarkan KTSP pada SD Negeri 42 Ampenan. Hal ini dapat dibuktikan bahwa dalam proses pembimbingan penyusunan RPP berdasarkan KTSP yang dilaksanakan sebanyak dua siklus telah mampu merubah kompetensi guru dengan data penguat sebagai berikut :

\begin{tabular}{|c|l|c|c|c|c|c|}
\hline No & \multicolumn{1}{|c|}{ Jenis kegiatan } & $\begin{array}{c}\text { Indikator } \\
\text { keberhasilan }\end{array}$ & $\begin{array}{c}\text { Siklus } \\
\text { I }\end{array}$ & Ket. & $\begin{array}{c}\text { Siklus } \\
\text { II }\end{array}$ & Ket. \\
\hline 1 & $\begin{array}{l}\text { Observasi Kepala } \\
\text { Sekolah }\end{array}$ & $\geq 4,0$ & 3,50 & $\begin{array}{l}\text { Belum } \\
\text { berhasil }\end{array}$ & 4,40 & Berhasil \\
\hline 2 & Observasi guru & $\geq 4,0$ & 3,53 & $\begin{array}{l}\text { Belum } \\
\text { berhasil }\end{array}$ & 4,27 & Berhasil \\
\hline 3 & hasil kerja individual & $\geq 85,00$ & 78,04 & $\begin{array}{l}\text { Belum } \\
\text { berhasil }\end{array}$ & 86,66 & Berhasil \\
\hline 4 & $\%$ Ketuntasan & $\geq 85 \%$ & $0 \%$ & $\begin{array}{l}\text { Belum } \\
\text { berhasil }\end{array}$ & $100 \%$ & Berhasil \\
\hline
\end{tabular}

Indikator keberhasilan dalam Penelitian Tindakan Sekolah (PTS) ini pada siklus II sudah dapat dibuktikan ( sudah terbukti ), maka Penelitian Tindakan Sekolah (PTS) dengan judul "Mengoptimalkan Pelaksanaan Pendampingan Berbasis KKG Upaya Meningkatkan Kompetensi Guru Kelas Dalam Penyusunan RPP Berdasarkan KTSP Di SD Negeri 42 Ampenan Semester Satu Tahun Pelajaran 2018/2019”, dan penelitian dihentikan pada siklus II.

\section{Saran-saran}

Kepada seluruh guru SD Negeri 42 Ampenan diharapkan kualitas proses pembelajaran di kelas senyatanya semakin menuju ke sistem pembelajaran yang aktif, inovatif, kreatif, efektif dan menyenangkan ( PAKEM) yang pada gilirannya nanti prestasi belajar siswa dapat ditingkatkan secara signifikan.

Kepada seluruh Kepala Sekolah sejawat disarankan untuk melakukan Penelitian Tindakan Sekolah (PTS) dalam upaya meningkatkan profesionalisme sebagai Kepala Sekolah yang mampu membangun karakter guru yang menjadi tanggung jawab dalam wadah Kelompok Kerja Guru (KKG). Melalui Penelitian Tindakan Sekolah (PTS) ini pula diharapkan Kepala Sekolah mampu 
meningkatkan kompetensi guru dalam proses pembelajaran dikelas senyatanya, sehingga guru tampil sebagai sosok yang dapat mengaktifkan siswa selama proses pembelajaran di kelas senyatanya. Posisi Kepala Sekolah sebagai mitra kerja dengan guru binaannya diharapkan mampu memiliki jenis pendekatan, strategi dan metode yang tepat yang harus diterapkan oleh guru ketika tampil dikelas senyatanya yang mampu membelajarkan siswa yang aktif, kreatif, demokratif, dan pembentukan karakter bangsa oleh siswa di dalam kehidupan sehari-hari.

\section{DAFTAR PUSTAKA}

Aswandi, 2010, Meningkatkan Kompetensi Guru PKn Pada Sekolah Binaan Dalam Penyusunan RPP berdasarkan KTSP Melalui Pendampingan Dan Perorangan Tahun 2012, Mataram: Jurnal Valid ISSN 1820-5037

Djaali, 2008, Psikologi Pendidikan, Jakarta: Bumi Aksara

Hartinah, S, 2009, Konsep Dasar Pendampingan, Bandung: Rafika Aditama

Kurniawan, A., \& Masjudin, M. (2017, December). Pengembangan Buku Ajar Microteaching Berbasis Praktik Untuk Meningkatkan Keterampilan Mengajar Calon Guru. In Prosiding Seminar Nasional Pendidik dan Pengembang Pendidikan Indonesia (pp. 9-16).

Kurniawan, A., \& Masjudin, M. (2017, December). PENGEMBANGAN BUKU AJAR MICROTEACHING BERBASIS PRAKTIK UNTUK MENINGKATKAN KETERAMPILAN MENGAJAR CALON GURU. In Prosiding Seminar Nasional Pendidik dan Pengembang Pendidikan Indonesia (pp. 9-16).

Ratno Harsanto, 2007, Pengelolaan Kelas Yang Dinamis Paradikma Baru Pembelajaran Menuju Kompetensi Siswa, Yogyakarta: Kanisius

Syahrir, S. (2010). Metodologi Pembelajaran Matematika. Yogyakarta: Naufan Pustaka. 